\title{
Malaysia’s Food Manufacturing Industries Productivity Determinants
}

\author{
Elsadig Musa Ahmed \\ Economics Unit, Faculty of Business and Law, Multimedia University, Melaka, Malaysia \\ Email: elsadigmusa@yahoo.com, asadiq29@hotmail.com
}

Received April 13, 2012; revised April 20, 2012; accepted May 28, 2012

\begin{abstract}
This study attempts to fill the gap in existing research on the drivers of total factor productivity growth (TFPG) in Malaysian food industries by employing a parametric statistical method and applying it to the country's food-manufacturing sector. Based on the model, the factors affecting output growth in Malaysian food industries are individual contributions of capital, labour, and materials, as well as the combined contributions of the quality of these inputs expressed as TFPG. Our results for the food-manufacturing sector depict characteristically low productivity levels. The contribution of TFP growth for 13 out of 27 food industries was negative during the full period of analysis (1971-2000) and the sub-period 1987-2000. Eleven industries were found to have contributed negatively to TFPG over 1971-1979 and 19801986. What explains our findings is the low quality of inputs into these food industries, which are input-driven rather than TFPG-driven.
\end{abstract}

Keywords: Productivity; Total Factor Productivity Growth; Malaysian Food Industry

\section{Introduction}

The food manufacturing industry in Malaysia plays a significant role in the economy. It serves not only as a source of employment but also a market outlet and added value for primary agricultural products. Under the Industrial Master Plan (IMP) for 1986-1995, the food processing industry was identified as a top priority for industrial development. This was determined on the basis of its potential contribution to manufacturing development, particularly with respect to employment generation, foreign exchange saving and value added creation. In addition, the rationale for the development of this sector lies with the fact that the industry has a strong linkage with other sectors of the Malaysian economy (MIDA) [1].

Food, a basic necessity, has always provided ample opportunities for investment. These opportunities were given a boost when the Malaysian Government chose the food-processing sector as a priority sector in the context of its industrial policy. The Government's intentions were to see further growth of the local food-processing sector, especially through the utilisation of the local raw materials. Relevant government policies such as the National Agricultural Policy (NAP) and the first and second IMPs (for 1986-1995 and 1996-2005) were established to promote and provide direction for the development of the sector.

There is however a dichotomy in the structure of the
Malaysian food processing sector. On the one hand, Malaysia has large food industries, which are well organised and use modern technologies. With ample capitalisation, they are in a position to keep abreast of the dynamic changes taking place in the sector; however, a large proportion of their raw material inputs are imported. On the other hand, the country has many labour-intensive medium and small industries (SMIs) which rely on lowlevel technologies. These SMIs are usually characterised by low levels of capitalisation, inefficient management, and constraints in access to credit, marketing, and supply of raw materials and labour. According to a 1990 survey by the Ministry of International Trade and Industry (MITI), [2] the food SMIs constitute the largest group among these, amounting to 32 percent of all SMIs (MIDA) [1].

We note a striking growth differential between this sector and other manufacturing industries in Malaysia MIDA, [1]. A number of factors are responsible for the imbalance, ranging from industry-related problems such as inconsistent supply and low quality of raw materials, high labour costs and lack of skilled manpower, difficulties in securing finance and poor technological inputs, to problems relating to changes and implementation of government policies for industrialisation.

Our study attempts to fill this gap by providing a parametric statistical analysis based on the growth decomposition framework, which employs the Translog Divisia Index approach developed by Jorgenson et al. [3], and 
applying it to assess productivity performance in Malaysian food manufacturing industries over 1971-2000.

The empirical literature on productivity performance of Malaysian industries has traditionally used two approaches to estimate TFPG: the growth accounting method, and econometric estimation methods. Employing the former approach, Syrquin [4] found TFPG of 3\% for 1960-1970 and 0.5\% for 1980-1989. Kawai [5] provided TFPG estimates of similar magnitude-2.5\% for 1970 1980 and $0.7 \%$ for $1980-1990$. Other studies based on the growth accounting framework include Gan \& Soon [6], who found TFPG of 1.6\% for 1974-1995 and 2.2\% for 1990-1995, and Ab. Wahab [7], who estimated TFPG of $1.3 \%$ and for $1990-1997$.

Econometric estimation-based studies include Thomas \& Wang [8], who found TFPG of 2\% between 1960 and 1987. A World Bank [9] report estimated TFPG of $1.3 \%$ during 1960-1990, while Gan \& Robinson [10] found that TFP was negative during the first half of the 1980s and positive over 1985-1991. Over a similar period, Zarina \& Shariman [11] also found negative TFPG estimates. However, econometric estimation-based studies fall short on calculating the individual contributions to TFPG of the explanatory variables considered.

\section{Estimation Technique}

We apply the conventional growth accounting framework utilised by Stigler [12], Abramovitz [13] and Kendrick [14], and developed by Solow [15,16], with further refinements from Kendrick [17] Denison [18,19], Griliches and Jorgenson [20] and Jorgenson et al. [3]. The output of each industry is a function of capital, labour, raw materials, and time. It is assumed that the production process is characterised by constant returns to scale for each industry, so that the proportional increase in all inputs results in a proportional change in output. Competitive equilibrium (where factors of production are paid the value of their respective marginal products) is also assumed. The production function for ith industry can be represented as follows:

$$
Q_{i}=F\left(K_{i}, L_{i}, M_{i}, T_{i}\right)
$$

where output $Q$ is a function of industrial capital input $K$, labour input $L$, intermediate input $M$, and time $T$, which proxies for technological progress of the food manufacturing industries.

The Divisia Index which is applicable to the above framework decomposes the output growth into the contribution of changes in inputs (such as capital, labour, and materials input growth) as well as TFPG. In other words, considering the data at any two discrete points of time, the growth rate of output $Q$ for an industry over the period can be expressed as a weighted average of the growth rates of capital, labour, and intermediate inputs, plus a residual term typically referred to as the rate of growth of TFP. Hence the TFPG of each industry is computed as the difference between the rate of growth of output and the weighted average of the growth in the capital, labour, intermediate inputs.

According to Mahadevan, [21] empirical TFPG studies of the Malaysian manufacturing sector have mostly used the nonparametric translog-divisia index approach developed by Jorgenson et al. [3]. While this approach does not require the explicit specification of a production function, its main drawback is that it is not based on statistical theory; hence statistical methods cannot be applied to evaluate its reliability. This study attempts to contribute to the literature by taking a parametric approach instead.

We proceed in steps, as follows:

$$
\begin{gathered}
\begin{aligned}
& \Delta \ln Q_{i, T}= a+\alpha\left(\Delta \ln K_{i, T}\right)+\beta\left(\Delta \ln L_{i, T}\right) \\
&+ \lambda\left(\Delta \ln M_{i, T}\right)+\varepsilon_{i, T} \\
& i=30 \text { and } T=1970-2000
\end{aligned}
\end{gathered}
$$

where, $i$ indexes the industries and $t$ indexes time; $\alpha$ is the output elasticity with respect to capital; $\beta$ is the output elasticity with respect to labour; $\lambda$ is the output elasticity with respect to material; $a$ is the intercept, $\varepsilon_{i, T}$ is the residual term (and proxies for TFPG which captures technological process through, e.g., the quality of inputs), and all the variables have been log-transformed to reduce the problem of heteroskedasticity. Furthermore, $\Delta$ denotes proportionate change rate and is the difference operator.

Since the intercept $a$ has no role in the calculation of growth rate and contribution of the productivity indicators, we propose a second step to calculate the growth rates and contribution of the productivity indicators. Equation (2) is transformed as:

$$
\begin{aligned}
& \Delta \ln \operatorname{TFP}_{i, T} \\
& =\Delta \ln Q_{i, T}-\left[\alpha\left(\Delta \operatorname{In} K_{i, T}\right)+\beta\left(\Delta \operatorname{In} L_{i, T}\right)+\lambda\left(\Delta \operatorname{In} M_{i, T}\right)\right] \\
& i=30 \text { and } T=1970-2000
\end{aligned}
$$

where $\Delta \ln Q_{i, T}$ is the growth rate of output, $\alpha\left(\Delta \ln K_{i, T}\right)$ is the contribution of capital, $\beta\left(\Delta \ln L_{i, T}\right)$ is the contribution of labour, $\lambda\left(\Delta \ln M_{i, T}\right)$ is the contribution of intermediate inputs, and $\Delta \ln \mathrm{TFP}_{i, T}$ is TFPG. Our framework thus decomposes the growth rate of output into the contributions of the rates of growth of capital, labour and material inputs, plus a residual term typically interpreted as TFPG.

\section{Results and Discussion}

We found that most coefficient estimates for input terms 
of food manufacturing industries were significant at the 5 and 10 percent statistical significance levels. DurbinWatson test values generally show no problem of autocorrelation, while the adjusted $\mathrm{R}^{2}$ values are quite high (Table 1). To avoid problems of non-stationarity and spurious correlations (Engel and Granger, [22]), we specify the model in first differences rather than in levels.

\section{Empirical Analysis}

We carry out the empirical analysis to compare the productivity indicators among the food manufacturing industries during 1970-2000 for gross value of output; value of fixed assets and real cost of input and employment figures (Source: Department of Statistics, Malaysia). Furthermore, in order to study the effect of government policies on sectoral productivity growth, we split the study period into three phases corresponding with the major policy changes, namely, 1971-1979, 1980-1986 and 19872000. The 1970s witnessed the birth of Malaysia's era of export-oriented economy. The 1980s saw further diversification of the economy into higher value-added industries. The last period considered (1987-2000) witnessed further diversification of the economy into more advanced industries.

Tables 2-5 show that output growth was positive for all food manufacturing industries over the full period and sub-periods considered. The contribution of capital input to the output growth of food manufacturing industries was mixed during the entire period and sub-periods of 1971-1979 and 1980-1986. Table 2 shows that the highest contribution of capital input in terms of the average annual growth rate was in the fish processing industry, and the lowest rate was in the coffee industry. The results indicates that the average annual growth rates of capital in the food manufacturing industries during 1987-2000 has outweighed the problems that were faced in the entire period and sub periods of 1971-1979 and 1980-1986. It also shows that there was a direct effect of government policies and plans that were applied to the food manufacturing industries which had faced declining growth rates after the structural transformation that took place in the Malaysian economy in 1987.

The labour input contribution to the food manufacturing industries output growth is presented in Tables 2-5. The average annual labour growth rates of some food industries reported a slowdown with negative growth rates. These industries are the other grain milling and biscuit factories industries. The slowdown of the labour input productivity growth could be attributed to the quality of labour input involved in the food manufacturing industries. This is in terms of labour contribution to total factor productivity growth that was mainly dominated by the factor of unskilled labourers and family owners whom have not attended any formal courses or training in food technology, but are merely following the traditional methods of food processing.

The material input contribution to the food manufacturing industry output productivity growth is shown in Tables 2-5. Even though Table 2 shows a slowdown in the average annual material growth rate, there were food industries averages whose annual growth rates of material input were high. The improvement of material productivity could be traced to the government policies that are supporting the position of food manufacturing among other non-resource-based industries. Those industries such as the electronics and electric industries especially in the sub periods of 1987-2000, contributed positively for most of the food industries. The slowdown of material inputs productivity growth rates could be attributed to the low quality of the raw materials and the technological inputs, which were mainly imported.

The use of total factor productivity overcomes the problem of single productivity indicators such as labour productivity and capital deepening by measuring the relationship between output and its total inputs (a weight sum of all inputs), thereby giving the residual output changes not accounted by total factor input changes. Being a residual, changes in total factor productivity are not influenced by changes in the various factors which affect technological progress. Examples here includes the quality of factors of production, flexibility of resource use, capacity utilisation, quality of management, economies of scale, and the like. Subsequently, the improvement and slowdown of total factor productivity contribution to food manufacturing industries in terms of average annual growth rates are dependent on the inputs used in the production of food industries, some of which were reported earlier to be of low quality and insufficient.

The contribution of total factor productivity growth to the food manufacturing industries' output growth was found to be positive, with only 13 out of 27 food industries showing negative growth during the entire period of the study. The highest contribution of total factor productivity growth came from the other dairy products industry $(3.0716 \%)$, based on the average annual growth rates. The lowest contribution on the other hand was from the manufacture of prepared animal feeds whose contribution was recorded as -21.746 percent (Table 2). Although the input terms contribution was improved during the sub period of 1987-2000, the total factor productivity growth declined to give a negative contribution in 13 out of 27 food industries, after the number of these industries had been reduced to 11 in the sub periods of 1971-1979 and 1980-1986. This was due to the fact that the problem of low quality of input terms in the food industries and productivity growth of Malaysian manufacturing industries is input driven rather than total factor 
Table 1. Output elasticity in food manufacturing industries, 1970-2000.

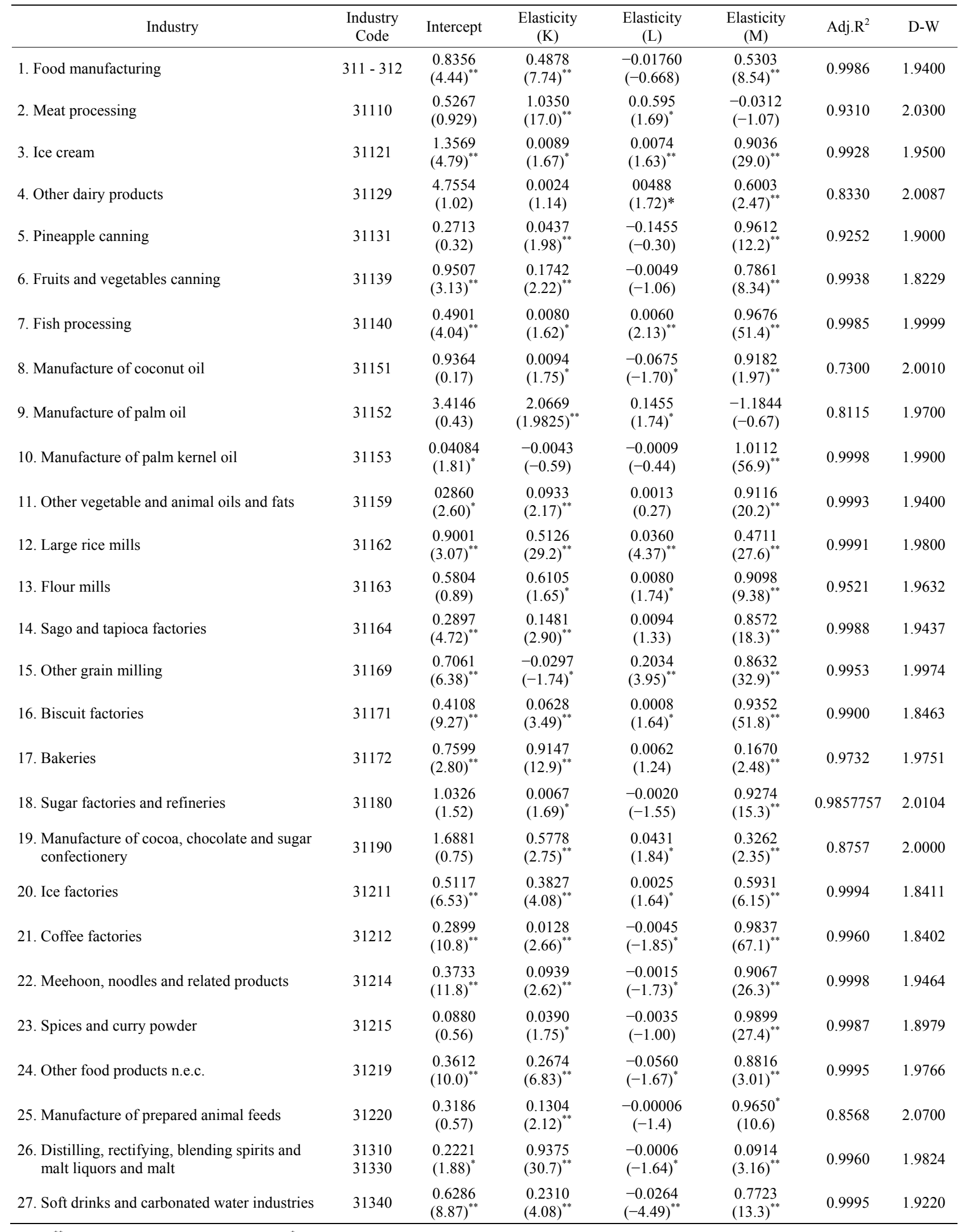

Notes: ${ }^{* *}$ Indicates SIGNIFICANT at 5\% level; ${ }^{*}$ Indicates significant at $10 \%$ level. 
Table 2. Productivity indictors in food manufacturing industries \%, 1970-2000.

\begin{tabular}{|c|c|c|c|c|c|c|}
\hline Industry Description & $\begin{array}{l}\text { Industry } \\
\text { Code }\end{array}$ & TFP & $\begin{array}{l}\text { Output } \\
\text { Growth }\end{array}$ & $\begin{array}{l}\text { Capital } \\
\text { Growth }\end{array}$ & $\begin{array}{l}\text { Labour } \\
\text { Growth }\end{array}$ & $\begin{array}{l}\text { Material } \\
\text { Growth }\end{array}$ \\
\hline 1. Food manufacturing & $311-312$ & -0.2574 & 11.174 & 12.192 & 29.060 & 11.421 \\
\hline 2. Meat processing & 31110 & 2.4053 & 18.328 & 15.388 & 7.1826 & 13.788 \\
\hline 3. Ice cream & 31121 & 0.2163 & 10.570 & 11.902 & 3.5678 & 11.310 \\
\hline 4. Other dairy products & 31129 & 3.0716 & 8.2017 & 8.3541 & 5.8201 & 8.0398 \\
\hline 5. Pineapple canning & 31131 & 0.0565 & 1.4971 & 3.4279 & 19.117 & -1.7433 \\
\hline 6. Fruits and vegetables canning & 31139 & -0.3652 & 9.4847 & 11.377 & 2.0841 & 10.022 \\
\hline 7. Fish processing & 31140 & -0.0536 & 12.451 & 17.539 & 30.144 & 12.607 \\
\hline 8. Manufacture of coconut oil & 31151 & 2.2535 & 3.3180 & 10.003 & 22.468 & 2.7088 \\
\hline 9. Manufacture of palm oil & 31152 & 1.6867 & 15.899 & 12.247 & 34.937 & 16.614 \\
\hline 10. Manufacture of palm kernel oil & 31153 & -0.3125 & 11.843 & -12.907 & 5.4606 & -11.347 \\
\hline 11. Other vegetable and animal oils and fats & 31159 & -0.8387 & 13.781 & -15.069 & 4.5799 & -1.2661 \\
\hline 12. Large rice mills & 31162 & -2.8517 & 18.379 & -15.100 & 25.974 & -18.519 \\
\hline 13. Flour mills & 31163 & 0.3738 & 4.8208 & 6.8906 & 3.0969 & 4.3961 \\
\hline 14. Sago and tapioca factories & 31164 & -0.5893 & 19.884 & -14.010 & -0.1807 & -20.087 \\
\hline 15. Other grain milling & 31169 & 0.0643 & 2.5626 & -2.5520 & -1.3326 & -2.8167 \\
\hline 16. Biscuit factories & 31171 & 0.4049 & 15.394 & -12.169 & 27.269 & -16.101 \\
\hline 17. Bakeries & 31172 & -1.9208 & 12.084 & -9.0138 & 31.439 & -12.667 \\
\hline 18. Sugar factories and refineries & 31180 & 0.5854 & 3.9472 & 1.4105 & 26.057 & 3.6709 \\
\hline $\begin{array}{l}\text { 19. Manufacture of cocoa, chocolate and sugar } \\
\text { confectionery }\end{array}$ & 31190 & -0.1886 & 12.469 & 14.464 & 6.2769 & 12.353 \\
\hline 20. Ice factories & 31221 & 0.4290 & 16.150 & -17.821 & 4.5052 & -16.472 \\
\hline 21. Coffee factories & 31212 & 0.5290 & 15.155 & -18.381 & 2.9487 & -15.689 \\
\hline 22. Meehoon, noodles and related products & 31214 & -0.0549 & 10.370 & -7.6598 & 6.0791 & -10.572 \\
\hline 23. Spices and curry powder & 31215 & 0.0202 & 13.320 & 16.729 & 6.4286 & 12.797 \\
\hline 24. Other food products n.e.c. & 31219 & -0.2540 & 17.034 & -13.134 & 31.581 & -16.990 \\
\hline 25. Manufacture of prepared animal feeds & 31220 & -21.746 & 37.295 & -11.732 & 27.342 & -14.163 \\
\hline $\begin{array}{l}\text { 26. Distilling, rectifying, blending spirits and } \\
\text { malt liquors and malt }\end{array}$ & $\begin{array}{l}31310 \\
31330\end{array}$ & 0.4560 & 16.772 & -16.752 & 21.633 & -16.507 \\
\hline 27. Soft drinks and carbonated water industries & 31340 & -0.6838 & 14.274 & -12.885 & 25.477 & -12.871 \\
\hline
\end{tabular}

productivity driven as found by previous studies. As for empirical evidence in the case of Malaysia, Maisom et al., [23], Choong and Tham [24] and Elsadig et al., [25], concluded that productivity growth in the Malaysian manufacturing industry is input driven rather than total factor productivity driven, and it is mainly dependent on Foreign Direct Investment (FDI). This was also con- firmed by Lall [26]. Newly industrialised Asian countries also have input driven productivity as stated by Young [27,28] and Kim and Lau [29]. Sarel [30] stated that some East Asian countries may face the same fate of the Soviet Union because these countries have invested primarily on labour and capital rather than in technology over the past few decades. 
Table 3. Productivity indictors in food manufacturing industries \%, 1971-1979.

\begin{tabular}{|c|c|c|c|c|c|c|}
\hline Industry Description & $\begin{array}{l}\text { Industry } \\
\text { Code }\end{array}$ & TFP & $\begin{array}{l}\text { Output } \\
\text { Growth }\end{array}$ & $\begin{array}{l}\text { Capital } \\
\text { Growth }\end{array}$ & $\begin{array}{l}\text { Labour } \\
\text { Growth }\end{array}$ & $\begin{array}{l}\text { Material } \\
\text { Growth }\end{array}$ \\
\hline 1. Food manufacturing & $311-312$ & 1.5246 & 31.768 & 35.145 & 33.775 & 31.053 \\
\hline 2. Meat processing & 31110 & 13.308 & 23.688 & 10.293 & -2.3117 & 4.3264 \\
\hline 3. Ice cream & 31121 & 1.1008 & 9.3236 & -61.232 & 3.8048 & 9.7771 \\
\hline 4. Other dairy products & 31129 & 7.2595 & 10.350 & 7.1393 & -71.689 & 10.950 \\
\hline 5. Pineapple canning & 31131 & 0.1592 & -2.6129 & 3.8079 & 0.0001 & -3.0571 \\
\hline 6. Fruits and vegetables canning & 31139 & -0.3264 & 19.594 & 23.025 & -64.350 & 19.829 \\
\hline 7. Fish processing & 31140 & 0.43365 & 22.718 & 29.131 & 19.908 & 22.665 \\
\hline 8. Manufacture of coconut oil & 31151 & 5.2294 & 0.6032 & 8.4242 & 76.136 & 4.7421 \\
\hline 9. Manufacture of palm oil & 31152 & 18.951 & 32.228 & 23.234 & 22.388 & 33.977 \\
\hline 10. Manufacture of palm kernel oil & 31153 & -1.8435 & 27.283 & 25.840 & -64.568 & 28.686 \\
\hline 11. Other vegetable and animal oils and fats & 31159 & -3.0397 & 25.763 & 28.902 & -68.804 & 28.737 \\
\hline 12. Large rice Mills & 31162 & -3.3910 & 2.9798 & 9.3156 & 4.5052 & 3.0421 \\
\hline 13. Flour mills & 31163 & 0.2968 & 1.7530 & 6.43352 & -73.718 & 1.8191 \\
\hline 14. Sago and tapioca factories & 31164 & -1.7980 & 5.0890 & 16.645 & 1.0330 & 5.1481 \\
\hline 15. Other grain milling & 31169 & 1.1657 & -32.072 & -35.985 & -18.468 & -35.388 \\
\hline 16. Biscuit factories & 31171 & 0.1908 & 4.9648 & 9.7695 & 4.5052 & 4.4446 \\
\hline 17. Bakeries & 31172 & -3.5813 & 5.0231 & 8.5187 & 7.7016 & 4.5729 \\
\hline 18. Sugar factories and refineries & 31180 & 0.6233 & 2.1068 & -2.5038 & 0.0570 & 1.6177 \\
\hline $\begin{array}{l}\text { 19. Manufacture of cocoa, chocolate and sugar } \\
\text { confectionery }\end{array}$ & 31190 & 1.4737 & 18.138 & 24.327 & -66.205 & 16.743 \\
\hline 20. Ice factories & 31221 & -0.5024 & 2.5028 & 3.1406 & 0.6391 & 3.3037 \\
\hline 21. Coffee factories & 31212 & 0.4742 & 4.3980 & -18.300 & 2.6994 & 4.2405 \\
\hline 22. Meehoon, noodles and related products & 31214 & -0.4224 & 19.409 & 24.977 & -67.061 & 19.170 \\
\hline 23. Spices and curry powder & 31215 & 0.8444 & 10.609 & 6.1465 & 4.2867 & 9.6366 \\
\hline 24. Other food products n.e.c. & 31219 & -0.5867 & -13.427 & -5.9630 & 0.5810 & -14.737 \\
\hline 25. Manufacture of prepared animal feeds & 31220 & -0.6059 & 8.8329 & 15.906 & 7.7016 & 8.8422 \\
\hline $\begin{array}{l}\text { 26. Distilling, rectifying, blending spirits and } \\
\text { malt liquors and malt }\end{array}$ & $\begin{array}{l}31310 \\
31330\end{array}$ & 3.8652 & 13.584 & 8.9014 & -7.7016 & 14.966 \\
\hline 27. Soft drinks and carbonated water industries & 31340 & -0.5388 & 12.530 & 11.611 & 4.5052 & 13.601 \\
\hline
\end{tabular}

\section{Conclusions and Policy Recommendations}

This study fills the gap of extensive growth theory model by providing statistical analysis in a parametric form which removes doubts in the results generated. The factors affecting the output growth in the food industries as identified in this study using the established model are the individual contributions of capital, the labour, the material and the combined contributions of the qualities of these inputs expressed as the total factor productivity growth.
The results indicated that there was an improvement in the food manufacturing industry's productivity growth following the implementation of the government policies to support the role of the food-manufacturing sector in Malaysia's economic development. Prior to 1987 (the period of structural transformation in the Malaysian economy), the agricultural sector as well as the industries related to it witnessed a decline in growth and contribution to the Malaysian economy. From the analysis in this study, it could be seen that the contribution of capital, 
Table 4. Productivity indictors in food manufacturing industries \%, 1980-1986.

\begin{tabular}{|c|c|c|c|c|c|c|}
\hline Industry Description & $\begin{array}{l}\text { Industry } \\
\text { Code }\end{array}$ & TFP & $\begin{array}{l}\text { Output } \\
\text { Growth }\end{array}$ & $\begin{array}{l}\text { Capital } \\
\text { Growth }\end{array}$ & $\begin{array}{l}\text { Labour } \\
\text { Growth }\end{array}$ & $\begin{array}{l}\text { Material } \\
\text { Growth }\end{array}$ \\
\hline 1. Food manufacturing & $311-312$ & -11.269 & -20.200 & -20.155 & -26.809 & -19.935 \\
\hline 2. Meat processing & 31110 & 1.1640 & 11.035 & 11.970 & -87.401 & -85.726 \\
\hline 3. Ice cream & 31121 & 2.1924 & 10.974 & 11.303 & 2.2569 & 8.5796 \\
\hline 4. Other dairy products & 31129 & 2.9493 & 6.7507 & 17.604 & 9.9021 & 5.4571 \\
\hline 5. Pineapple canning & 31131 & -1.3003 & -4.3237 & -3.2412 & -9.9021 & -3.0131 \\
\hline 6. Fruits and vegetables canning & 31139 & 0.2477 & 8.2692 & 10.249 & 0.0156 & 7.8251 \\
\hline 7. Fish processing & 31140 & -1.0513 & 2.6391 & 40.733 & -5.7924 & 3.5107 \\
\hline 8. Manufacture of coconut oil & 31151 & -0.0315 & -4.3370 & 30.578 & -2.4484 & -5.1842 \\
\hline 9. Manufacture of palm oil & 31152 & 12.941 & 8.2879 & 2.7693 & 0.9219 & 8.9522 \\
\hline 10. Manufacture of palm kernel oil & 31153 & 0.6525 & -8.7167 & -8.9563 & 0.0018 & -8.6459 \\
\hline 11. Other vegetable and animal oils and fats & 31159 & 2.1283 & -9.2163 & -1.0714 & 0.0004 & -9.2464 \\
\hline 12. Large rice mills & 31162 & -6.1968 & -9.7513 & -8.9493 & 4.1097 & -9.6774 \\
\hline 13. Flour mills & 31163 & -0.8132 & 10.296 & 7.7757 & 0.0008 & 11.689 \\
\hline 14. Sago and tapioca factories & 31164 & 1.4263 & -9.7139 & -9.7139 & 1.1665 & -9.7803 \\
\hline 15. Other grain milling & 31169 & -0.8231 & 16.227 & 11.719 & 5.0200 & 18.972 \\
\hline 16. Biscuit factories & 31171 & 0.4383 & -8.6739 & -7.4140 & 7.2975 & -8.8247 \\
\hline 17. Bakeries & 31172 & 1.7978 & -8.7592 & -8.1492 & 1.9902 & -8.9263 \\
\hline 18. Sugar factories and refineries & 31180 & 0.7727 & 2.5804 & -7.6242 & 0.0670 & 2.0046 \\
\hline $\begin{array}{l}\text { 19. Manufacture of cocoa, chocolate and sugar } \\
\text { confectionery }\end{array}$ & 31190 & -1.3804 & 11.875 & 15.009 & 5.7924 & 13.286 \\
\hline 20. Ice factories & 31221 & 0.4533 & -8.9425 & -9.2772 & 5.2498 & -9.1701 \\
\hline 21. Coffee factories & 31212 & -0.2256 & -9.3067 & -8.5393 & -9.6643 & -9.93703 \\
\hline 22. Meehoon, noodles and related products & 31214 & 0.7171 & -8.7205 & -8.3007 & 5.7924 & -8.8353 \\
\hline 23. Spices and curry powder & 31215 & -0.5672 & 25.427 & 28.770 & 10.018 & 25.158 \\
\hline 24. Other food products n.e.c. & 31219 & 0.8854 & -9.2000 & -8.2909 & 0.0010 & -9.2676 \\
\hline 25. Manufacture of prepared animal feeds & 31220 & 0.4959 & -8.8787 & -8.0539 & 0.0015 & 0.8935 \\
\hline $\begin{array}{l}\text { 26. Distilling, rectifying, blending spirits and } \\
\text { malt liquors and malt }\end{array}$ & $\begin{array}{l}31310 \\
31330\end{array}$ & -3.8163 & -9.2201 & -9.2201 & 9.9021 & 1.4696 \\
\hline 27. Soft drinks and carbonated water industries & 31340 & -1.9788 & -9.7210 & -8.9593 & 0.5053 & 1.4621 \\
\hline
\end{tabular}

labour and material of food manufacturing industries improved during the first and second Industrial Master Plans (1986-1995 and 1996-2005). These plans were designed to improve the productivity performance of twelve industries among which is the food manufacturing industry. In contrast, the contribution of total factor productivity growth of 13 out of 27 food industries was found to be negative during the entire period and subperiod of 1987-2000. 11 industries were also reported to have contributed negatively during the sub-periods of
1971-1979 and 1980-1986. This has been attributed to the problem of low quality of input terms of the food industries and productivity growth of Malaysian manufacturing industries, which is actually input-driven rather than total factor productivity-driven, as found by previous studies.

This study shows that the food manufacturing industry is an important sector in Malaysia's economic development. The first and second Industrial Master Plans (1986-1995 and 1996-2005) identified the food manufacturing Indus- 
Table 5. Productivity indictors in food manufacturing industries \%, 1987-2000.

\begin{tabular}{|c|c|c|c|c|c|c|}
\hline Industry Description & $\begin{array}{l}\text { Industry } \\
\text { Code }\end{array}$ & TFP & $\begin{array}{l}\text { Output } \\
\text { Growth }\end{array}$ & $\begin{array}{l}\text { Capital } \\
\text { Growth }\end{array}$ & $\begin{array}{l}\text { Labour } \\
\text { Growth }\end{array}$ & $\begin{array}{l}\text { Material } \\
\text { Growth }\end{array}$ \\
\hline 1. Food manufacturing & $311-312$ & 4.1027 & 14.520 & 14.310 & 13.964 & 14.190 \\
\hline 2. Meat processing & 31110 & -3.9827 & 18.529 & 20.372 & 60.578 & 69.726 \\
\hline 3. Ice cream & 31121 & -1.2808 & 11.169 & 8.3533 & 4.0708 & 13.661 \\
\hline 4. Other dairy products & 31129 & 0.4405 & 7.5463 & 4.5103 & 53.607 & 7.4602 \\
\hline 5. Pineapple canning & 31131 & 0.6689 & 0.6335 & 6.5183 & 45.915 & 0.2637 \\
\hline 6. Fruits and vegetables canning & 31139 & -0.7352 & 3.5935 & 4.4301 & 45.834 & 4.8161 \\
\hline 7. Fish processing & 31140 & 0.1318 & 10.757 & -5.8163 & 54.692 & 10.690 \\
\hline 8. Manufacture of coconut oil & 31151 & 1.4829 & 8.8907 & 7.3040 & 0.4262 & 8.0919 \\
\hline 9. Manufacture of palm oil & 31152 & -17.827 & 8.0931 & 9.5348 & 64.192 & 8.0611 \\
\hline 10. Manufacture of palm kernel oil & 31153 & 0.3260 & 4.0775 & 4.1715 & 66.232 & 3.6981 \\
\hline 11. Other vegetable and animal oils and fats & 31159 & -0.9261 & 3.7440 & 7.5486 & 67.536 & 4.2512 \\
\hline 12. Large rice mills & 31162 & -0.8323 & 7.4580 & 6.4006 & 50.707 & 6.7485 \\
\hline 13. Flour mills & 31163 & 1.1970 & 3.8465 & 6.7000 & 67.916 & 1.8635 \\
\hline 14. Sago and tapioca factories & 31164 & -0.8203 & 2.5100 & 7.8472 & -1.6346 & 2.5477 \\
\hline 15. Other grain milling & 31169 & -0.2000 & 7.0131 & 11.805 & 6.5070 & 7.2277 \\
\hline 16. Biscuit factories & 31171 & 0.5258 & 7.1915 & 4.7129 & 51.889 & 6.7647 \\
\hline 17. Bakeries & 31172 & -2.2712 & 14.672 & 15.954 & 57.467 & 14.1455 \\
\hline 18. Sugar factories and refineries & 31180 & 0.4353 & 6.3227 & 10.362 & 63.957 & 6.4112 \\
\hline $\begin{array}{l}\text { 19. Manufacture of cocoa, chocolate and sugar } \\
\text { confectionery }\end{array}$ & 31190 & -0.6614 & 9.1212 & 7.8515 & 53.114 & 9.0638 \\
\hline 20. Ice factories & 31221 & 1.0156 & 8.4970 & 6.1786 & 6.6183 & 8.5998 \\
\hline 21. Coffee factories & 31212 & 0.9415 & 11.231 & 15.073 & 52.905 & 10.506 \\
\hline 22. Meehoon, noodles and related products & 31214 & -0.2047 & 8.9038 & 9.0328 & 53.241 & 9.1990 \\
\hline 23. Spices and curry powder & 31215 & -0.2158 & 9.0089 & 17.512 & 6.0106 & 8.6489 \\
\hline 24. Other food products n.e.c. & 31219 & -0.6099 & 18.130 & 17.143 & 67.673 & 19.404 \\
\hline 25. Manufacture of prepared animal feeds & 31220 & -4.6456 & -4.1202 & 4.9045 & 53.638 & 8.6440 \\
\hline $\begin{array}{l}\text { 26. Distilling, rectifying, blending spirits and } \\
\text { malt liquors and malt }\end{array}$ & $\begin{array}{l}31310 \\
31330\end{array}$ & 4.0065 & 5.0306 & 4.4807 & 46.357 & 5.0094 \\
\hline 27. Soft drinks and carbonated water industries & 31340 & -0.1295 & 9.9629 & 9.7213 & 51.697 & 11.925 \\
\hline
\end{tabular}

try sector as a priority industry among twelve industries that must contribute to Malaysia's industrial development. The importance of the food-manufacturing sector, besides its connection with many Malaysia's economic sectors, is in its influence on the nation's diet. Furthermore, it plays a role as a strategic product, especially in time of political fluctuations and in the advent of war or famine. Therefore, the starting point for the policy recommendations is to offer policies that can help overcome the main problems of the food-manufacturing sector, es- pecially the inefficiency and low productivity.

Aimed at any industry to develop there must be a regular and consistent supply of raw materials. With the exception of palm oil, an estimated $70 \%$ of the raw materials required by the Malaysian food industries are imported. Improvement of the quality of the local raw materials will help to improve the final products. This will enable them to compete in the international markets and also help to reduce the dependency of the Malaysian food industries on imported raw materials. The level of skilled 
labour employed would usually reflect on the level of technology adopted. Therefore, before any improvements are implemented on technological and material inputs, there is the need to reduce the number of unskilled persons dominating the Malaysian economy in general and food industries in percale, and increase the amount of skilled labour in these industries. Technological input has been identified as a major constraint facing the Malaysian food manufacturing industry. The findings of this study reflected the relationship between technological inputs and the scale of production of small-scale food industries. Low technologies are adopted in the manufacturing processes, and the manual handling of materials is applied with low-quality control. The first step towards improving the productivity growth of the Malaysian food industries will be to modernise the technology used by small-scale industries in order to improve the quality of the food industries products, as well as to change their production methods. This must be started from the cultivation of the agricultural raw materials, in order to reduce the harvesting loss and also to produce good quality raw materials. Programmes should be designed to upgrade the small-medium industries (SMIs) involved in the food industries and to enable them to play an active role in Malaysia's industrial development.

Family members who have little or no training in food technology operate most SMIs in the food manufacturing industry. This poses a lot of management problems to the food manufacturing industry, in addition to existing financial problems faced by the food manufacturing industry due to its position in the manufacturing industry sector.

Finally, the limitation of this study is that the department of statistics of Malaysia has changed the industrial classification codes of these industries; it made it very difficult to extend the data of these industries beyond 2000. In this regards, this study is limited to 2000 , however there is changes in the reality of productivity of Malaysia's food industries if the data is extended beyond 2000.

\section{REFERENCES}

[1] Malaysian Industrial Development Authority (MIDA), "Medium and Long term Industrial Master Plan Malaysia (1986-1995)," Malaysian Industrial Development Authority, Kuala Lumpur, 1985.

[2] Ministry of International Trade and Industry (MITI), “Annual Report 1993-1995," Ministry of International Trade and Industry Kuala Lumpur, 1985.

[3] D. W. Jorgenson, F. M. Gollop and B. Fraumenri, "Productivity and US Economic Growth," Harvard University Press, Cambridge, 1987.

[4] M. Syrquin, "A Comparative Analysis of Structural Transformation in Latin America," In: M. Urrutia, Ed., Long-
Term Trends in Latin American Economic Development, Johns Hopkins University Press, Washington DC, 1991, pp. 81-116.

[5] H. Kawai, "International Comparative Analysis of Economic Growth: Trade Liberalization and Productivity," Developing Economies, Vol. 11, No. 4, 1994, pp. 373-397.

[6] W. B. Gan and L. Y. Soon, "Input versus Productivity Driven Growth: Implications for the Malaysian Economy," In: L. Y. Soon and N. Shyamala, Eds., The Seventh Malaysia Plan: Productivity for Sustainable Development, University Malaya Press, Kuala Lumpur, 1998.

[7] A. Wahab, "Total Factor Productivity Growth: Survey Report," Asian Productivity Organization, Tokyo, 2004.

[8] V. Thomas and Y. Wang, "Distortions, Interventions, and Productivity Growth: Is East Asia Different?" Economic Development and Cultural Change, Vol. 44, No. 2, 1996, pp. 265-288. doi:10.1086/452213

[9] World Bank, "The East Asian Miracle: Economic Growth and Public Policy," Oxford University Press, New York, 1993.

[10] W. B. Gan and E. Robinson, "Aggregate Supply and Wage Price Mechanism: Some Implications for Inflation Stabilization in Malaysia," HIID-ISIS Seminar, Kuala Lumpur, 1993.

[11] Z. A. Zarina and A. Shariman, "Growth, Inflation and Potential Output," Central Bank Discussion, Kuala Lumpur, 1994.

[12] G. J. Stigler, "Trends in output and Employment," National Bureau of Economic Research, New York, 1947.

[13] M. Abramovitz, "Resource and Output Trends in the United States since 1870," American Economic Review, Vol. 46, No. 2, 1956, pp. 5-23.

[14] J. W. Kendrick, "Productive Trends Capital and Labour," Review of Economics and Statistics, Vol. 38, No. 3, 1956, pp. 248-257. doi:10.2307/1925777

[15] R. M. Solow, "The Production Function and the Theory of Capital," Review of Economics Studies, Vol. 21, No. 2, 1956, pp. 101-108.

[16] R. M. Solow, "Technical Change and the Aggregate Production Function," Review of Economics and Statistics, Vol. 39, No. 3, 1957, pp. 312-320. doi:10.2307/1926047

[17] J. W. Kendrick, "Productivity Trends in the United States," Princeton, Princeton University Press, 1961.

[18] E. F. Denison, "The Sources of Economic Growth in the United States and the Alternative before Use," Committee for Economic Development, New York, 1962, pp. 229-255.

[19] E. F. Denison and P. Edward, "Accounting of Slower Economic Growth; the United States in the 1970s," The Brooking Institution, Washington DC, 1979.

[20] Z. Griliches and D. W. Jorgenson, "Capital Theory: Technical Progress and Capital Structure, Sources of Measured Productivity Change Capital Input," American Economic Review, Vol. 52, No. 1, 1962, pp. 50-61.

[21] R. Mahadevan, "Assessing the Output and Productivity Growth of Malaysia's Manufacturing Sector," Journal of Asian Economics, Vol. 12, No. 4, 2001, pp. 587-597. doi:10.1016/S1049-0078(01)00104-X 
[22] R. F. Engle and C. W.J Granger, "Time-Series Econometrics: Cointegration and Autoregressive Conditional Heteroskedasticity," Nobel Prize Committee, Stockholm, 2003.

[23] A. Maisom, H. M. Ariff and N. Aini, "Productivity and Efficiency in Malaysian Manufacturing Sector," First Malaysian Econometrics Conference, Kuala Lumpur, 6-7 April 1993.

[24] L. Choong and S. Y. Tham, "Total Factor Productivity in the Malaysian Manufacturing Sector Preliminary Results," Jurnal Ekonomi Malaysia, Vol. 29, 1995, pp. 9-35.

[25] E. M. Ahmed, A. Khalid, Y. Zulkornain Y. and A. Zakariah, "Factors Determining Malaysian Manufacturing Sector Productivity Growth," Asia Pacific Economics and Business Conference 2002 Theme: The Impact of Global Competitive Environment on Asian Economics, Business and Society, Kuching, 2-4 October 2002.

[26] S. Lall, "Malaysia: Industrial Success and the Role of the
Government," Journal of International Development, Vol. 7, No. 5, 1995, pp. 775-789. doi:10.1002/jid.3380070506

[27] A. Young, "A Tale of two Cities: Factor Accumulation and technological Change in Hong-Kong and Singapore," National Bureau of Economic Research, Macroeconomics Annual, Vol. 7, 1992, pp. 13-54.

[28] A. Young, "The Tyranny of Numbers: Confronting the Statistical Realities of the East Asian Growth Experience," Quarterly Journal of Economics, Vol. 110, No. 3, 1995, pp. 641-680. doi:10.2307/2946695

[29] J. I. Kim and L. Lawrence, "The Sources of Economic Growth of the East Asian Newly Industrialized Countries," Journal of Japanese and International Economies, Vol. 8, No. 3, 1994, pp. 235-271. doi:10.1006/ijie.1994.1013

[30] M. Sarel, "Growth in East Asia: What We Can and Cannot Infer," IMF Working Paper 95/98, International Monetary Fund, Washington DC, 1996. 